To the Editors:

\title{
Characterisation of a bladder cancer cohort in a urological unit
}

Published data on urological malignancies in Sri Lanka are scarce and those in print are constrained by low patient numbers and short follow up periods. A large number of urological malignancies are never referred to the national oncological centre in the country. Hence, data from it suffers a serious selection bias (2).

A descriptive study was done on patients with newly diagnosed bladder tumour between 1 November 1999 and 31 December 2001 at one of the two units of a tretiary care urology centre.

A total of 139 patients were histopathologically diagnosed to have bladder cancer during the two year period. Baldder tumour is a predominantly disease of the aged. In our study only 16 out of $145(11 \%)$ were below the age of 50 years. It was commonest in the seventh decade. The sex ratio (M: F, 9:1) was much higher than the figures quoted in the literature (M: F, 3:1) (1). The almost exclusive prevalence of tobacco smoking among Sri Lankan men, which is a major known cause of bladder tumour could be the explanation (1).

An overwhelming majority (96\%) of tumours were transitional cell carcinomas (TCC), of which 88\% (123/139) were early stage (Tis-T2) tumours (TNM classification). Of the early tumours $80 \%$ were of the low grades (Ash histological grading). Overall $75 \%$ of the TCC cases were at or below pT2G $_{1}$ Nx (Table 2). Only four (2.8\%) had synchronous upper tract tumours and these data compare well with the reported figures (1) from other countries.

We have observed an inconsistency between the clinical and pathological staging. Only in $41 \%$ was the prediction accurate. More often the clinical assessment was an overestimate of the stage compared to histological confirmation $(55 \%)$ due to absence of bladder muscle to assess the degree of invasiveness. When there is a mismatch it is reasonable to biopsy again or to consider adjunctive therapy giving the clinical stage appropriate consideration (5).

Mortality of TCC is directly related to the pathological stage and grade (4). Of the 10 cancer related deaths in our study, 3 had advanced stage tumours (pT3 and T4) and 5 of the deaths were of the 37 high grade (G III) group (Table 1).

Our study showed a significant dropout rate from the surveillance program for bladder tumour recurrence. Instead of the expected number of 172 patients moving in to the second year, only 150 did so (Table 2). This emphasises the need for an active surveillance and information system instead of the patient dependent passive request method currently practiced in our system.
Table 1. The stage and the histological grade of TCC

$\begin{array}{ccc}\begin{array}{c}\text { Number } \\ \text { of patients }(\%)\end{array} & \begin{array}{c}\text { pStage } \\ (\text { TNM })\end{array} & \begin{array}{c}\text { Grade } \\ (\text { Ash })\end{array} \\ 1(0.7) & \text { Tis } & - \\ 14(10) & \mathrm{Ta} & \text { I } \\ 1(0.7) & & \text { II } \\ 1(0.7) & & \text { III } \\ 22(16) & \mathrm{T} 1 & \text { I } \\ 45(32) & & \text { II } \\ 12(8.6) & & \text { III } \\ 9(6.4) & \mathrm{T} 2 & \text { I } \\ 7(5) & & \text { II } \\ 11(7.9) & & \text { III } \\ 0 & \mathrm{~T} 3 & \text { I } \\ 3(2.1) & & \text { II } \\ 10(7.1) & & \text { III } \\ 0 & \text { T4 } & \text { I } \\ 0 & & \text { II } \\ 3(2.1) & & \text { III }\end{array}$

Table 2. Relationship of endoscopic workload of bladder tumour in the context of the total cystocopy service

$\begin{array}{lcr}\text { Description } & \text { Year 2000 } & \text { Year 2001 } \\ \text { Total cystoscopy sessions for the year } & 946 & 1118 \\ \text { Bladder tumour related cystoscopy sessions } & 538 & 617 \\ \begin{array}{l}\text { Number of bladder tumour } \\ \text { patients for cystoscopy }\end{array} & 181 & 232 \\ \text { Newly diagnosed patients of bladder tumour } & 67 * & 82 \\ \text { Mortality } & 9 * * & 5 \\ \text { Carried forward patients for next year } & 172 & 227 \\ \text { Brought forward from last year } & 114 & 150\end{array}$

* includes 4 patients with upper tract tumour alone.

** 4 patients were diagnosed before 1 November 1999.

\section{References}

1. Messing EM, Catolana WJ. Urothelial tumors of the urinary tract. In Walsh PC, Retik AB, Vaughan Jr. Wein AJ, eds. Campbell's Urology 7th edn. Vol. III, Chapt 77. Philadelphia: Saunders, 1998: 2327-2391.

2. Goonewardena SAS, de Silva WAS. Pattern of urological malignancy in Sri Lanka: experience from a tertiary referral centre. Ceylon Medical Journal 1999; 44: 100-1.

3. Morrison AS, Burning JE, Wendy G, Verhoek WG, Kunio A, et al. An international study of smoking and bladder cancer. Journal of Urology 1984; 131: 650-4.

4. Richard L, Droller MJ. The natural history of bladder cancer. Urologic Clinics of North America 2000; 27: 1-13.

5. Marshall VF. The relation of preoperative estimate to the pathologic demonstration of the extent of vesical neoplasms. Journal of Urology 1952; 68: 714.

Neville D Perera, Urological Surgeon, National Hospital of Sri Lanka, Colombo. (Correspondence NDP email: nev603@sltnet.lk telephone+94 1 778061). 